\title{
A Metaphoric Case: Thoughts of Pre-Service Turkish Teachers Related to Literary Qualified Children's Books
}

\author{
Oğuzhan YILMAZ ${ }^{1}$ \\ ${ }^{1}$ Erzincan University, Faculty of Education, Elementary Education Department, Erzincan, Turkey \\ Correspondence: Oğuzhan YILMAZ, Faculty of Education, Elementary Education Department, Erzincan \\ University, 24000 Erzincan, Turkey. E-mail: oyilmaz@erzincan.edu.tr
}

Received: September 10, 2015 Accepted: October 14, 2015 Online Published: March 29, 2016

doi:10.5539/ies.v9n4p236

URL: http://dx.doi.org/10.5539/ies.v9n4p236

\begin{abstract}
The world has been changing, information sources have been diversifying; and the importance of reading book has been gradually increasing. Books' constituting a place in life children as vitally important in developing their learning and imagination depends upon their close surrounding and essentially their learning Turkish. Therefore, in this study, the perceptions of pre-service Turkish teachers related to literary qualified children's books were tried to be determined. The study was a phenomenological research carried out benefiting from the qualitative research tradition. The sample of the study that was carried out in a state university in Anatolia included 27 students chosen through maximum variation sampling among the students studying at Turkish Teaching department of the relevant state university. Data of the research were collected through open ended written interview form and semi-structured interview form; and the obtained data were coded and categorized performing content analysis. At the end of the study, it was revealed that pre-service Turkish teachers emphasized educative dimension of literary qualified children's books as well as their content properties through the metaphors they used and relatively kept the properties such as language and narration in the background.
\end{abstract}

Keywords: children's literature, literary qualified children's book, pre-service Turkish teacher

\section{Introduction}

The world has been changing, information sources have been diversifying; and the importance of reading book has been gradually increasing. Books' constituting a place in life children as vitally important in developing their learning and imagination depends upon their close surrounding and essentially their learning Turkish. Considerations of Turkish teachers related to books in general and children's book special meaning, their discourses on books and thoughts related to books will strengthen or weaken the attachment of children with books. However, it was noticed when the relevant literature was reviewed that the studies revealing the thoughts of Turkish teachers or pre-service Turkish teachers related to literary qualified children's books were limited. In fact, general ideas of pre-service Turkish teachers on children's books are essential in order to create an attachment between children and books and to raise mentally and emotionally healthier individuals. Therefore, perceptions of pre-service Turkish teachers related to literary qualified children's books were tried to be determined in this study.

Children's book that can be defined as written products that are prepared for children, contributing upon language, thought, emotion and imagination development of children and spending good time was considered as an instrument that provides opportunity for children to have awareness on different branches of fine arts, and create first love towards their native language, and as an effort to raise individuals of future by Sever (2000). Children's books that contribute upon children and their development have numerous benefits such as developing imagination, comprehension skill, analysis and synthesis power, vocabulary, general culture, thinking diversity, sympathy establishment, problem solving, and expressing themselves (Serafini \& Moses, 2014; Kılıç, 2006; Şimşek, 2007; Sınar-Çılgın, 2007). Obtaining these benefits at a maximum level is possible through children's books having specific qualities. In the relevant literature, beside the researchers that classified the qualities children's books should include under general style and content titles (Şimşek, 2007; Ciravoğlu, 2000; Kıbrıs, 2006; Oğuzkan, 2010; Gürel, Temizyürek, \& Şahbaz 2007), there were also researchers that added language and narration properties to the current classification as a different title as being different from this classification (Sınar-Çılgıı, 2007; Nas, 2004). 
In the light of this classification, the first of important qualities children's books have to have could be mentioned to be style, in other words outer structure (Anderson, 1985). The factors such as size, type of paper, page layout, printing technique, letters, pictures, cover and cover layout that could be evaluated within the outer structure properties should reflect a design approach that will encourage children to reading as a whole as mentioned by Yazıci-Okuyan (2009). So much so that, children should understand the importance and respect given to an instrument produced for themselves from the elaborative design that is integrated with outer structure (stylistic) properties of the books.

Another criterion that should be regarded in a literary qualified children's book include the aspects related to content properties. As mentioned by Tekin, "The aspect that should probably be regarded most in children's books is content (2000). " Content properties that will directly affect the temper of children and shape the criteria in perceiving the dream and truth include the factors such as theme, subject, heroes, plot and plan. If these factors are related to interest, expectations and curiosity of children, children will read the book fondly; otherwise will stop reading (Ataseven \& İnand1, 2000).

The last criterion that should be regarded in children's books includes the factors related to language and narration properties. Sever who emphasized that the most important property that determine the children's books' being for children was language and narration regarded a literary qualified children's book as an instrument that introduces vocabulary presence of a language and provides children to have sensitivity (2010). On the same subject, Tekin revealed the importance of aspects such as vocabulary, sentence, figures of speech, alliteration, articulation and narration competence in children's books mentioning that "No matter how important and necessary information a book includes and an interesting subject it narrates, if you cannot find the soft and fluent use of the language, ending a book turns into torture (2000)."

After mentioning the aspects related to style, content, language and narration properties in literary qualified children's books in general meaning, theme of a publishing based artistic work can be specified to be integrated with its plan, pictures, style, language, and narration (Kaplan, 2000). However, when the relevant literature was reviewed, the situations seemed slightly more different than it should be. The current literature referred that pre-service Turkish teachers did not equally regarded the factors such as style, content or language and narration necessary to be considered in qualified children's books and evaluated literary qualified children's books only focusing on one of these aforementioned factors.

For instance, in the research carried out by Yazıc1-Okuyan (2009) upon the selection criteria of Turkish and classroom teachers for the children's literature products used during the reading time, it was determined that positive views of teachers related to outer structure criteria were at a low level, and the teachers participated into the research regarded interior structure properties more. In the research, educative criteria of children's books were the ones all teachers agreed most. It was remarkable in the research that teachers wanted to see more direct messages rather than the hidden indirect messages in literary qualified children's books. Similar to the findings of Yazıci-Okuyan, it was also noticed in researches of Arslan and Alamdar (2011) that pre-service Turkish teachers primarily regarded content properties of books while suggesting the books students should read. It was also determined that the pre-service teachers regarded language and narration of books at a decreasing level subsequently. In the research carried out by Temizkan (2011) upon the perception of pre-service Turkish teachers towards the properties children's books should include, results contrast to the aforementioned study findings were obtained. According to the research of Temizkan, whereas pre-service Turkish teachers had a level of knowledge above the average about the properties children's books should have in their outer structure, they had no adequate knowledge on content, and language and narration. Although it was carried out upon pre-service pre-school teachers, when the study of Öztürk-Samur (2011) titled as competences of pre-service pre-school teachers for selecting the children's literature products, it was noticed that findings of Temizkan were repeated. Öztürk-Samur noticed in the interviews he performed with pre-service pre-school teachers that they mostly emphasized the outer properties of books. He revealed in his research that pre-service teachers did not mention the inner structure properties of the children's books much. Despite not revealing as definite result as the researches mentioned above, significant findings were also revealed in the research of Maltepe (2009) upon the selection competence of pre-service Turkish teachers for the products of children's literature. In the research it was noticed that pre-service teachers regarded more about the children's books upon their being didactic, reflecting their imagination, having a theme attracting children and relevant to the real life, being appropriate to children's culture and being written in a fluent and understandable language. It was also noticed in the evaluation related to stylistic properties of qualified children's book in the research that pre-service teachers mentioned visual elements (especially pictures), printing properties, font size and point size more.

As could be seen in the relevant literature, pre-service teachers had different ideas related to the qualifications 
necessary to be included in literary qualified children's books. In the sense, the research was essential in order to determine what they thought on literary qualified children's books, to establish a relationship between books and children, to learn views of pre-service Turkish teachers related to the literary qualified children's books and provide specific guidance. For that purpose, views of pre-service Turkish teachers related to literary qualified children's books were tried to be determined through metaphors in the study.

\section{Method}

\subsection{Research Design}

The study was a phenomenological research carried out benefiting from the qualitative research tradition. " $A$ phenomenological study is an inductive descriptive research design focusing on human fact (Baş \& Akturan, 2013)". In a phenomenological study, individuals describe their experiences on phenomena (Creswell, 2014). Aims, behaviors and perceptions of individuals direct the phenomenological research process (Jasper, 1994). In this research, phenomenological design was used because thoughts of teachers related to the children's books were tried to be learned through metaphors.

\subsection{Study Sample}

The study was carried out in a state university in Anatolia. Twenty-seven students chosen randomly through maximum variation sampling method among the students studying at Turkish Teaching Department of the relevant state university were included into the sample of the study. The purpose to collect data through maximum variation sampling method in the study was "...to create a relatively small sample and to reflect variation of individuals possible to be part of a problem studied in this sample at a maximum level (Ylldirim \& Simşek, 2011)." In the relevant study, the students studying at the $3^{\text {rd }}$ grade of Turkish Teaching Department were classified into three groups including to be successful at upper, medium, and low level according to their children's literature course mid-term exam scores, and nine students from each group were chosen as the data source in order to provide this variety.

\subsection{Data Collection}

Before collecting the data of the study, the lecturer lecturing the children's literature course was contacted, and permission was obtained from the lecture of the course for the study to be carried out. Subsequently, contact was established with the pre-service teachers via the lecturer having the role of key information provider, and students were informed about the purpose, subject, and necessity of the study to be carried out. In order to prevent possible ethical problem, precautions to be taken were shared with the pre-service teachers, and the pre-service teachers that would provide data to the study were provided to feel free about being a part of the current scientific study. After necessary informing, pre-service teachers mentioned that they did not consider to support the study as risky and signed previously prepared consent form.

After taking the permission of pre-service teachers to be included into the study, data of the research were collected through a written form including a standardized open-ended question and a semi-structured interview performed to support this form.

\subsubsection{Standardized Open Ended Written Interview Form}

Before preparing the standardized open-ended interview form, the relevant literature was reviewed, and two question templates that will measure the perceptions of pre-service teachers towards literary qualified children's book were prepared. Secondly, these question templates were shown to totally three people including one children's literature specialist, one assessment and evaluation specialist, and one language specialist, and one of these two question templates was agreed. In order to determine to what extent this template could serve to the intended idea, a pilot implementation was performed to 10 students who were not included to the current study. As result of the pilot implementation, it was retested that the current question template had the quality that would provide data for the study. Subsequently, the data necessary for the study was collected presenting the template sentence of "Children's books resemble to ... Because ..." to the pre-service teachers through a sample instruction. The reason for using standardized open-ended interview form in the study was not to take much time of participants and to facilitate the data analysis (Patton, 2014).

\subsubsection{Semi-Structured Interview Form}

By the worry of pre-service teachers could experience some difficulties in expressing themselves adequately through a standardized open-ended written interview form, data of the study was also collected through semi-structured interview form. So that both some disadvantages of standardized open-ended interview form such as not entering into the world of participant was overcome (Merriam, 2013), and changes were possible to 
be made in content based upon the concept at times. The semi-structured interview was made with 6 pre-service teachers chosen among the pre-service teachers from whom data were obtained through standardized open-ended interview form. During the interview, the question template of "Children's books resemble to ...Because ..." addressed previously to the pre-service teachers was readdressed in different forms. A trust-based environment was tried to be created in order to provide pre-service teachers feel psychologically relaxed during the interview, and the interview was recorded via a voice recorder taking the permission of the pre-service teachers.

\subsection{Data Analysis}

Data of the study were analyzed in two ways. Firstly, the data obtained through the standardized open-ended interview form were read for a few times, and then coded by the researcher and a qualitative research specialist and subjected to the content analysis. In the content analysis, the process is to gather similar data together within the frame of specific concepts and themes, and to interpret these organizing in a way the reader can understand (Yıldırım \& Şimşek, 2011). Secondly, the scheme of the data obtained from the pre-service teachers via the voice recorder was performed by the researcher, and the schemed data were subjected directly to the content analysis as in the standardized open-ended interview form. It is also necessary to mention here that data collection and data analysis processes progressed one within the other, and analysis was constant during each process of the study.

\subsection{Validity and Reliability}

In order to provide the study to have a scientific identity, some precautions were taken during the study process. The first of these precautions was during the coding process. So as to provide coding reliability of the study, reliability tests based upon time and observation were carried out, and the study was concluded to be reliable. Whereas time-based reliability means measuring the fact in the same way within the passing time, observation-based reliability means more than one researchers' measuring a fact or event in the same way within the same time period (Yıldırım \& Şimşek, 2011).

Another precaution taken for the validity and reliability of the study was to diversify the data collection methods. The data collected through standardized open-ended interview form in the study were recollected from 6 pre-service teachers in the same group in order to provide conclusiveness, and the obtained data were used for data richness and verification.

Apart from these, the data set was revised for many times in order to increase validity and reliability of the study, a logical chain was tried to be established among the information, direct quotations were frequently used in order to remain loyal to the obtained data, and participant confirmation was asked for after writing findings and interpretations section.

\section{Findings and Interpretation}

\subsection{Thoughts of Pre-Service Turkish Teachers Related to Style Properties of Literary Qualified Children's Books}

Pre-service Turkish teachers used fairly limited number of metaphors related to stylistic properties of literary qualified children's books. Only 4 out of totally 27 pre-service teachers emphasized the stylistic properties of literary qualified children's books through metaphors. For example, 5 numbered pre-service teacher resembled children's books to non-living flowers. For the student, the reason for this situation was children's books decorating the libraries, but having no more properties apart from this. Moreover, 5 numbered student expressed his/her perception related to children's books mentioning that "Children's books have no smell like non-living flowers; however, these books are magnificent in terms of their colors and shape. Although they do not grab attention in their subjects, they are at a high point in their cover and shape," and stated that children's books were weak in terms of their content and at a high point in terms of their style. Another pre-service teacher mentioned that "They attract people through their elaborate covers. They provide the opportunity of travelling to different worlds or different places communing with the heroes in the book by means of their attractive colors of the pictures inside (S 4)" trying to grab attention to the stylistic properties of these books resembling the children's books to a decorative toy, and emphasized the book covers and illustrations. Twenty-seven numbered pre-service teacher who used metaphor especially for the book cover page resembled children's books to a house, and conveyed the idea that the cover pages of children's books are as important as the outer appearance of a house. The pre-service teachers supported his thought through the expressions as "Cover and volume design in children's books should attract children, and should be appropriate to the development and age of children. As the outer appearance of a house attracts a tenants and make them say "This house should be mine," the cover page and volume of the books should attract children and make them say "This book should be mine."

One of the pre-service teachers trying to emphasize the stylistic properties of children's books resembled 
children's books to an amusement park, and expressed this as mentioning "Like the amusement instruments in an amusement park as being ostentatious and colorful, children's books are also colorful and distinctive (S 6)." The metaphors used by the pre-service Turkish teachers and considered to be associated with stylistic properties of the children's books were presented in Figure 1.

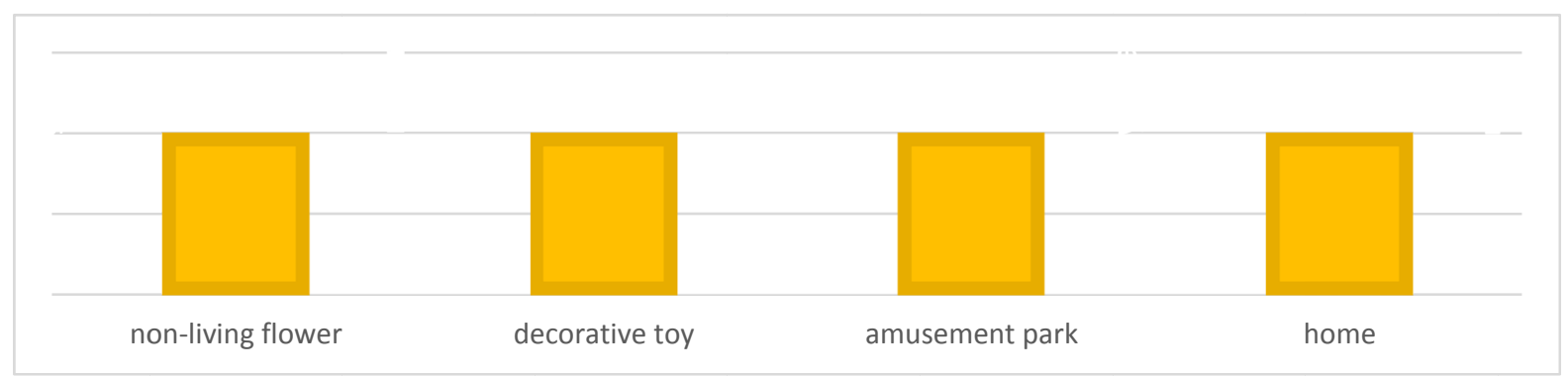

Figure 1. The metaphors pre-service Turkish teachers use for the style properties of literary qualified children's books

\subsection{Thoughts of Pre-service Turkish Teachers Related to Content Properties of Literary Qualified Children's Books}

While the pre-service Turkish teachers were mentioning about the children's books, they mostly addressed content properties in general, and educational properties within the scope of the content properties of children's books, in particular. The metaphors of the pre-service teachers used interesting metaphors related to the educative properties of children's books were generally about books' shaping, guiding, and amusing properties.

Cake mold resemblance of 13 numbered pre-service teacher who gave prominence to the shaping property of children's books was remarkable in this aspect. According to the 13 numbered pre-service teacher, children's books are generally not different from the cake molds used to prevent cake's spilling to anywhere unintentionally while baking. Like the 13 numbered pre-service teacher who grabbed attention to the shaping effect of children's books, 9 numbered pre-service teacher also resembled children's books to a wheat processing mill, and addressed shaping and filing effects of the children's books mentioning that 'I resemble children's books to a wheat processing mill. Stacks of wheat is brought to this mill, and turns into grain after processing. The wheat that becomes anther in the field turns into grain in the mill. Similarly, children are processed, shaped like the wheat brought to the mill." Another pre-service teacher that resembled children's books to a field addressed shaping effect of the children's books through the metaphors mentioning that "You grow what you plant, and you harvest this growing product. The children's books are also the same. How the authors or poets want children to be grown and shape their feelings and thought, they plant ideas to their books like planting seeds to a field (21)."

There were also pre-service teachers addressing the guiding dimension of children's books through the metaphors they used after the thought of narrow scope shaping. In this aspect, 26 numbered pre-service teacher who resembled children's books to the traffic signs emphasizing that "Children's books lead children and give messages to them about what is correct and what is wrong like the traffic signs." Similarly, 15 numbered pre-service teacher resembled children's books to the fireflies stating that "I have always resembled children's books to the fireflies; fireflies work hard harmlessly, and always give out light to their surroundings. Children's books pull those lovely creatures we call as children into their own world, lighten them and open a window in their mind" and these sentences were possible to be considered in sense of guiding property of the children's books. Also 16 numbered pre-service teacher referred guiding dimension of the children's books through the metaphors mentioning that "Children's books resemble to a rainbow. Like the rainbow, children's books have no only one color. It includes several colors... Children's books do not narrate only one thing. They are colorful, they draw children inside. They narrate both good and bad things." Apart from these, Turkish teachers expressed in a sub-message that children's books were required to be guiding through preferring the metaphors such as mother, world, ship, teacher, and marathon runner.

Another point pre-service Turkish teachers emphasized through the metaphors they used like guiding was learning entertainingly. Twenty-five numbered pre-service teachers who used the metaphor of toy related to the idea of learning entertainingly expressed his/her thoughts mentioning that "I resemble children's books to toys. 
Children talk to their toys, play with them and spend their time as they do with children's books" and referred that children's books help children entertain, learn and spend their time. 11 numbered pre-service teacher who resembled children's books to toys like 25 numbered pre-service teachers grabbed attention to the learning entertainingly function of children's books using sentences such as "As children get pleasure and learn many things when their play with a beneficial toy, they will both get pleased and learn many things when they read children's books." Another pre-service teacher used a metaphor on this preferred a similar metaphor even not the same with the previous pre-service teachers. On this aspect, 19 numbered pre-service teacher who resembled children's books to a playground expressed that the children who learned the life entertaining in playgrounds were possible to learn the life entertaining through the books.

Another prominent thought related to the content properties in metaphors used by pre-service Turkish teachers apart from the educative dimension of children's books included the properties related to literature. For example, 19 numbered pre-service teacher resembled children's books to a snowball, and justified this thought as "Because books are basis for children to acquire a literary pleasure as childhood. As obtaining a bigger snowball by rolling, children's books provide literary pleasure in children to grow and develop gradually." Although not directly as in 19 numbered pre-service teacher, 3 numbered pre-service teacher referred some literary qualities through the metaphors mentioning that "Children's books resemble to a magic carpet. Whenever they want, the magic carpet takes children away from the merciless, colorless, dark world, and fly them into a colorful and vivacious planet..." Subsequently, the pre-service teacher expressed while listing some qualities related to the children's books that children's books were required to take children away from narrow, misty, and disappointing world of adults and call them beyond Mount Kaf. Another pre-service teacher who mentioned the qualities related to literature through the indirect metaphors resembled children's books to a magic wand all children would like to have. The pre-service teacher explained this as "Children's books are full of things we would like to do but we cannot. The narrated events are extraordinary. People's living the things they will never experience in children's books and making their dreams come true create a magic wand effect."

The last aspect pre-service Turkish teachers referred related to the content properties included the thought of innocence. One of the pre-service teachers who resembled children's books to a planet said that "Children's books remind me my childhood. Childhood is a world where everything is clean and money is only an instrument to become happy (S 14);" and 10 numbered pre-service teacher expressed his view on innocence as "Children's books resemble to snow, snow is innocence. And children's book is a concrete object including that childish innocence and sensitivity." The metaphors used by the pre-service teachers and considered to be relevant to content properties of literary qualified children's books were presented in Figure 2.

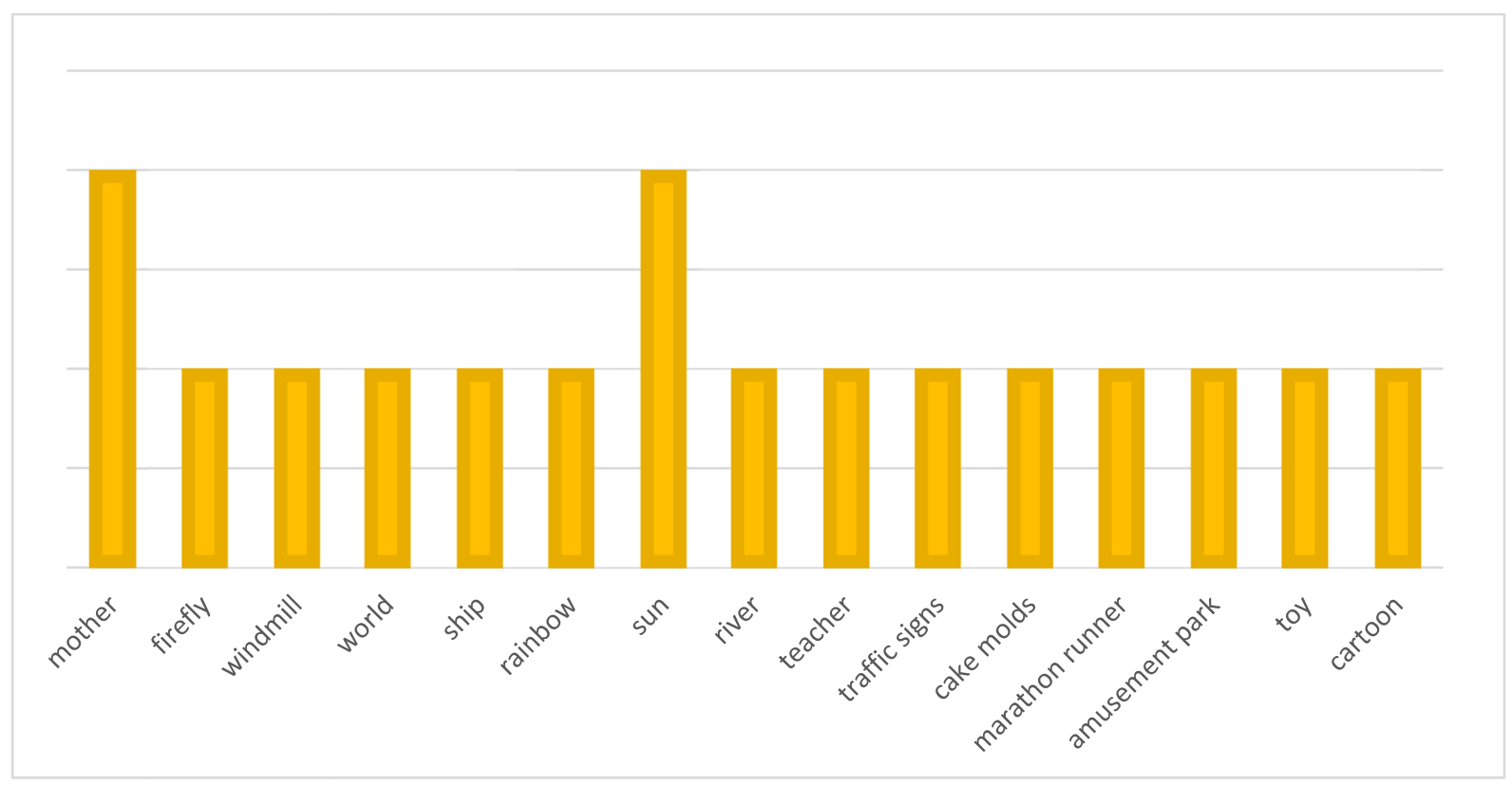

Figure 2. The metaphors pre-service Turkish teachers use for the content properties of literary qualified children's books 


\subsection{Thoughts of Pre-service Turkish Teachers Related to Language and Narration Properties of Literary Qualified Children's Books}

In the study, the dimension pre-service Turkish teachers addressed as the least in the metaphors they used was the narration and language properties of literary qualified children's books. Extremely strikingly, only three pre-service teachers used metaphors related to the narration and language properties of children's books. For example, 17 numbered pre-service teacher resembled children's books to a mother and reported that children's books provided contribution upon vocabulary development of children mentioning that "Like mothers who develop their children's vocabulary through the lullabies and tongue twisters they teach, children's books enhance vocabulary of children like a mother." Eleven numbered student who resembled children's books to the toys emphasized that narration and language properties of children's books should have importance for children mentioning "As families think whether this toy is proper to my child's age and level while choosing a toy, they also put forward their ideas about whether the content, and language and narration properties of the book is proper to my child while choosing a book." The metaphors used by the pre-service teachers and considered to be relevant to language and narration properties of literary qualified children's books were presented in Figure 3.

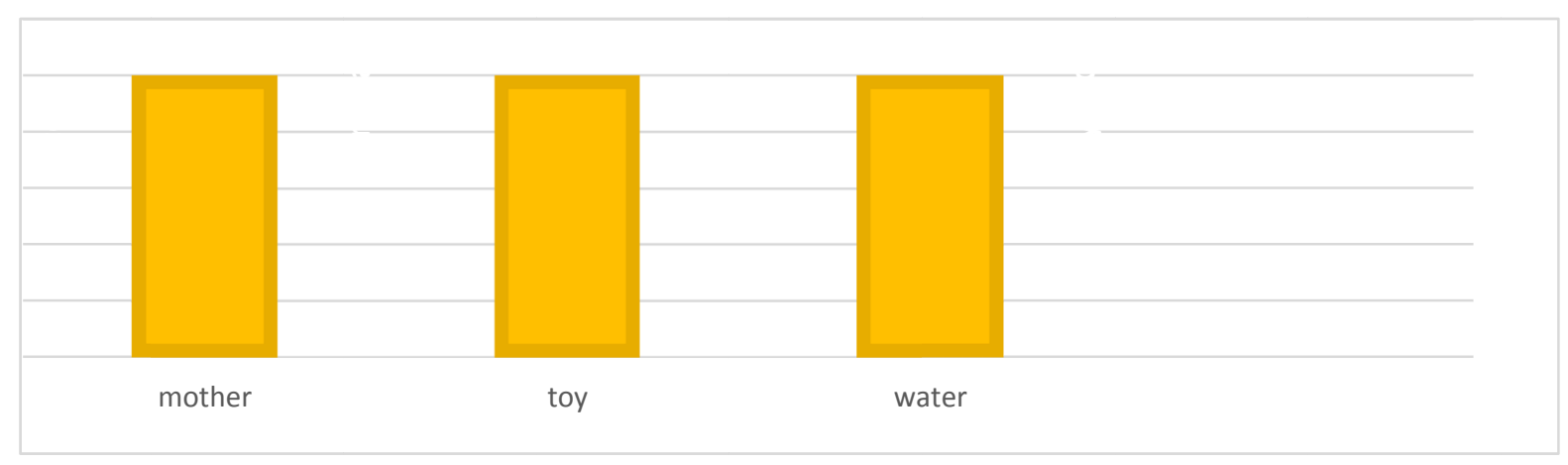

Figure 3. The metaphors pre-service Turkish teachers use for the language and narration properties of literary qualified children's books

\section{Conclusion and Discussion}

In the study, thoughts of pre-service Turkish teachers related to literary qualified children's books were tried to be determined through metaphors. In reference to the metaphors pre-service teachers used, it was noticed that they mostly emphasized content properties of the children's books, and they rarely referred other qualities required to be included in children's books such as style, and language and narration.

One of the aspects pre-service Turkish teachers referred even a little through the metaphors they used included the stylistic properties of literary qualified children's books. Pre-service Turkish teachers who generally perceived picture, cover and volume design as the stylistic qualities have never referred other factors related to the stylistic properties of children's books such as the size, type of paper, page order and letters. Although this was similar to the findings of Maltepe (2009), the studies differed in some aspects. Maltepe determined in his study in which he tried to specify the selection competences of pre-service Turkish teachers for the children's literature products that pre-service teachers mostly referred visual elements (pictures), printing properties, font size and point size related to stylistic properties of children's books. It was noticed here that, findings of both studies corresponded to each other, especially on pictures. Different from Maltepe, pre-service Turkish teachers' not mentioning stylistic properties of literary qualified children's books could be arisen from this study's design. However, it was necessary to state here that even at a metaphor level, describing children's books upon some content-based properties and forgetting that children's books were one in their style, content, and language and narration properties would cause some problems in terms of the pre-service teachers who will establish the relationship of children with books.

The dimension pre-service Turkish teachers referred most related to the content properties through the metaphors were the educative aspect of the literary qualified children's books. This understanding of pre-service Turkish teachers who emphasized the functions of literary qualified children's books such as shaping, guiding, and learning entertainingly could be arisen from their considering children's books as an educative instrument. Indirect guiding of children's books could be beneficial in case they were adumbration-based in accordance with 
the nature of children during the process of teaching entertainingly; however, shaping understanding that was prominent in books is worrisome in terms of being a compliment to "engaged and ideological" children's literature. Here it should not be ignored that didactic quality in literary qualified children's books is at a sensitive line and the dose of this sensitivity should be adjusted well. Apart from this, pre-service Turkish teachers' using metaphors related to education in terms of content was not an incidence. Similar findings were noticed to be in the relevant literature. For example, in the research carried out by Yazıc1-Okuyan (2009), it was understood that educative criteria of the children's books were especially regarded by teachers, and teachers preferred direct messages rather than the indirect ones in books. Similarly, in the study carried out by Arslan and Alamdar (2011), as well, pre-service teachers gave prominence to the educative aspect of children's books as in this study, and considered that children's books should be entertaining and didactic. Moreover, in the study of Maltepe (2009), pre-service teachers emphasized that children's books were required to be didactic.

Although Turkish teachers generally referred content properties of children's books and used metaphors related to education, a group of pre-service teachers indicated the literary properties literary qualified children's books should include through the metaphors they used. However, the number of pre-service teachers who looked for some indicators related to literature in children's books was limited. The pre-service teachers who revealed their perceptions related to the education of children through the metaphors they used pushed the importance of literature, literary pleasure and imagination in literary qualified children's books into the background. However, some sentences related to literature were essential in literary qualified children's books. As in general, education should not move ahead of literature in literary qualified children's books; the author should not put readers in a line like a teacher.

In the study, pre-service Turkish teachers did not refer another content property of literary qualified children's books apart from the "education" and "literature" aspects through the metaphors they used. Despite this, content properties were the one pre-service teachers mentioned mostly. This was also supported in the literature. The researches carried out by Yazıci-Okuyan (2009), and Arslan and Alamdar revealed that teachers and pre-service teachers regarded content properties in children's books more. The research carried out by Temizkan (2011) was in contrast to the aforementioned research findings. The findings of Temizkan who determined that perceptions of pre-service Turkish teachers related to the content properties of children's books were low in his study could be arisen from the sample in his study and the lecturer influencing that sample.

Another dimension that was weak according to the thoughts of pre-service Turkish teachers related to the content properties of literary qualified children's books included language and narration properties. According to the metaphors pre-service Turkish teachers used, style, and especially language and narration properties that were fairly in the background according to the style properties, were included in the study in general words such as "vocabulary, language and style" being indicated by a few pre-service teachers. Although it could not be concluded here that pre-service teachers did not regard language and narration properties, it was possible to mention that some qualities related to language and narration were in the background rather than the content and style properties in children's books. This invalidated the thought of Sever (2010) who considered that the most important aspect that provided children's books to be proper to children was language and narration. When the relevant literature was reviewed, it was also noticed that the aspects related to language and narration in children's books were not considered as prominent by teachers and pre-service teachers. For example, in his study, Temizkan stated that Turkish teachers did not have adequate knowledge on language and narration. In this study, pre-service Turkish teachers' not making a sentence on any aspects such as sentences, figures of speech, rhetoric, and narration competence partially supported what Temizkan stated.

In conclusion, it was possible to mention that pre-service Turkish teachers emphasized content properties of literary qualified children's books, especially the educative aspect of children's books more through the metaphors they used, and relatively put the properties such as style, and language and narration in the background. In reference to these, the idea of "Lecturers who lecture undergraduate degree children's literature to the pre-service Turkish teachers should equally regard each dimension of literary qualified children's books" was possible to be offered as a suggestion.

\section{References}

Anderson, C. C. (1985). Style and language in children's books. Children's literature association, 10/3, 113-114.

Arslan, F., \& Alamdar, S. G. (2011). Türkçe ve sınıf öğretmeni adaylarının çocuk edebiyatı ve çocuk edebiyatı dersine ilişkin görüşleri. 3. Ulusal Çocuk ve Gençlik Edebiyatı Sempozyumu (pp. 39-45). Ankara: Ankara University.

Ataseven, F., \& İnandı, Y. (2000). Çocuk kitaplarının çeşitli yönleriyle incelenmesi. 1. Ulusal Çocuk Kitapları 
Sетровуити (pp. 187-206). Ankara: Ankara University.

Baş, T., \& Akturan, U. (2013). Nitel araştırma yöntemleri. Seçkin Yayıncılık: Ankara.

Ciravoğlu, Ö. (2000). Çocuk edebiyatı. İstanbul: Esin Yayınevi.

Creswell, J. W. (2014). Research design (S. B. Demir, Trans.). Eğiten Kitap Yayınları: Ankara.

Gürel, Z., Temizyürek, F., \& Şahbaz, N. K. (2007). Çocuk edebiyatı. Öncü Kitap Yayınları: Ankara.

Jasper, M. (1994). Issues in phenomenology for researchers of nursing. Journal of Advanced Nursing, 19, 309-314. http://dx.doi.org/10.1111/j.1365-2648.1994.tb01085.x

Kaplan, M. (2000). Çocuk kitaplarında resimleme, içerik, dil ve anlatım özellikleri. 1. Ulusal Çocuk Kitapları Sетроzуити (pp. 551-565). Ankara: Ankara University.

Kıbrıs, İ. (2006). Çocuk edebiyatı. Tek Ağaç Yayınevi: Ankara.

Maltepe, S. (2009). Pre-service Turkish teachers' adequacies of selecting children's literature products. Ballkesir University the Journal of Social Sciences Institute, 12(21), 398-412.

Merriam, S. B. (2013). Qualitative research a guide to design and implementation (S. Turan, Trans.). Nobel Yayınları: Ankara.

Nas, R. (2004). Çocuk edebiyatt. Ezgi Kitabevi: Bursa.

Oğuzkan, F. (2010). Çocuk edebiyatı. Anı Yayınları: Ankara.

Öztürk-Samur, A. (2011). Okulöncesi öğretmen adaylarının nitelikli çocuk edebiyatı eserlerini seçebilme yetkinlikleri. 3. Ulusal Çocuk ve Gençlik Edebiyatı Seтровуити (pp. 219-228). Ankara: Ankara University.

Patton, M. Q. (2014). Qualitative research \& Evaluation methods (M. Bütün \& S. B. Demir, Trans.). Pegem Akademi Yayınları: Ankara.

Serafini, F., \& Moses, L. (2014). The roles of children's literature in the primary grades. The Reading Teacher, $67 / 6,465-468$.

Sever, S. (2000). Çocuk kitaplarında dilsel ve görsel duyarlık. 1. Ulusal Çocuk Kitapları Sempozyumu (pp. 631-646). Ankara: Ankara Üniversitesi.

Sever, S. (2010). Çocuk ve edebiyat. Tudem Yayınları: İzmir.

Şimşek, T. (2007). Çocuk edebiyatı. Suna Yayınları. Konya

Sınar-Çılgın, A. (2007). Çocuk edebiyatı. Morpa Yayınları: İstanbul.

Tekin, H. (2000). Çocuk kitaplarında bütünsellik. 1. Ulusal Çocuk Kitapları Sempozyumu (pp. 448-458). Ankara: Ankara University.

Temizkan, M. (2011). The perception ability of the candidates of Turkish- language teachers about features found in child's books. Gazi University Journal of Gazi Educational Faculty, 31(2), 339-357.

Yazıci-Okuyan, H. (2009). The criteria of Turkish teachers and class teachers in choosing the children's books for reading hour. Mehmet Akif Ersoy University Journal of Education Faculty, 9(18), 135-159.

Yıldırım, A., \& Şimşek, H. (2011). Sosyal bilimlerde nitel araştırma yöntemleri. Seçkin Yayıncılık: Ankara.

\section{Copyrights}

Copyright for this article is retained by the author(s), with first publication rights granted to the journal.

This is an open-access article distributed under the terms and conditions of the Creative Commons Attribution license (http://creativecommons.org/licenses/by/3.0/). 